PAWEŁ OLSZEWSKI, ADRIAN CHOJAN

DOI : $10.14746 /$ rie.2017.11.10

Instytut Studiów Politycznych PAN, Warszawa

\title{
Rywalizacja Unii Europejskiej i Rosji na obszarze Bałkanów Zachodnich
}

\section{Wprowadzenie}

Geopolityczna rywalizacja między Unią Europejską a Federacją Rosyjską jest na stałe wpisana w funkcjonowanie obu tych podmiotów stosunków międzynarodowych. Nie ma przy tym większego znaczenia fakt, że pierwszy z nich jest organizacją międzynarodową, zrzeszającą na ten moment 28 państw członkowskich, a ten drugi klasycznym państwem federalnym. Oba te podmioty mają jednak określone interesy geopolityczne i geoekonomiczne, które nie raz były już przedmiotem sporów i rywalizacji. Dotyczy to nie tylko obszaru Bałkanów Zachodnich, ale także innych, równie ważnych zakątków Europy i świata, podając za przykład chociażby kontynent afrykański.

To co jednak różni Unię Europejską od Federacji Rosyjskiej, to sposób osiagania geopolitycznych celów w polityce międzynarodowej. Podczas gdy UE pozostaje wierna podejściu idealistycznemu, zakładającemu bezproblemową współpracę państw opartą na zrozumieniu, konsensusie i pokoju, o tyle Rosja preferuje podejście realistyczne, zakładające, że tylko dzięki potędze i sile można realizować założone interesy narodowe. W przypadku Unii Europejskiej mamy do czynienia z tzw. miękką siłą (soft power), której podstawę stanowi kultura, ideologia i sposób uprawiania polityki. Przywódcy europejscy już od 1993 roku starają się uatrakcyjniać wdrażany przez nich model integracji europejskiej, jako przykład dobrobytu, demokracji i rządów prawa. Dzięki temu członkostwo w UE stało się dla wielu państw priorytetem ich polityk zagranicznych, podając za przykład Polskę, Czechy, Słowację, Rumunię czy ostatnio Chorwację. Zupełnie inaczej poszerzanie swojej strefy wpływów rozumiała Federacja Rosyjska. Trudno powiedzieć, aby na „,kontrolowanych” przez nią obszarach na pierwszy plan wysuwały się dobrobyt, demokracja i prawa człowieka. Rosja od lat prowadzi swoją imperialną politykę przy użyciu dosyć skutecznej propagandy (przykład Białorusi i Mołdawii). Ponadto, w przeciwieństwie do UE, nie stosuje zasady warunkowości, jako instrumentu integracji czy zacieśniania współpracy. W przypadku integracji z UE, potencjalne państwa członkowskie dostrzegają korzyści w dłuższej perspektywie czasu, zaś w przypadku współpracy z Rosją efekty są praktycznie od razu. Jednym z przykładów może być udzielanie wysokich pożyczek finansowych państwom takim jak, np. Białoruś. Ten realistyczny obraz rosyjskiej polityki wydaje się stać w zupełnej sprzeczności z polityką Unii Europejskiej. Należy jednak pamiętać, że UE to nie tylko obszar demokracji, rządów prawa i prawdziwej europejskiej kultury. To przede wszystkim arena z jednej strony, rywalizacji państw członkowskich o realizację własnych celów narodowych, a z drugiej, zgodnie z podejściem reali- 
stycznym, to instrument umacniania ich bezpieczeństwa międzynarodowego. Zgodnie $\mathrm{z}$ ideą integracji europejskiej, im więcej państw zostanie włączonych $\mathrm{w}$ ten proces, tym większa szansa na międzynarodowy pokój i bezpieczeństwo.

Zważywszy na doświadczenia historyczne państw Bałkanów Zachodnich i stale istniejące napięcia między ich narodami, trudno nie zgodzić się z tezą, że obszar ten może stać się miejscem bezpośredniego, politycznego starcia Unii Europejskiej z Federacją Rosyjską. Wiele w tej materii zależy od Czarnogóry, Serbii, Albanii czy Republiki Macedonii. To, jaką ostatecznie drogę wybiorą te kraje, będzie jednocześnie wyznacznikiem dalszych relacji unijno-rosyjskich w tym regionie, ale i nie tylko w tym. Może się wydawać, że państwa Bałkanów Zachodnich nie mają innej alternatywy dla członkostwa w Unii Europejskiej. Takie rozumowanie było właściwe jeszcze kilka lat temu. Obecnie zaś, wskutek wewnętrznych problemów UE (migracja, UE dwóch prędkości), w tym braku zdecydowania co do dalszego rozwoju UE, przywódcy tych państw zgłaszają coraz większe wątpliwości co do intencji Brukseli, domagając się realnego wsparcia dla realizowanych przez nich reform wewnętrznych (Woźniak, 2015).

Celem niniejszego artykułu jest wskazanie głównych obszarów rywalizacji między Unią Europejską a Federacją Rosyjską na obszarze Bałkanów Zachodnich. Albania, Macedonia, Czarnogóra i Serbia posiadają oficjalny status państw kandydujących do UE. Nie należy jednak zakładać a priori, że w ciagu kilku lat staną się państwami członkowskimi UE. Wskutek spadku atrakcyjności projektu europejskiego i coraz bardziej aktywnej polityki zagranicznej Federacji Rosyjskiej może się okazać, że zmienią wektory polityk zagranicznych, kierując się w stronę Rosji. Paradoksalnie bowiem Rosja ma czym „kusić” owe państwa, począwszy od zapewnienia bezpieczeństwa energetycznego po udzielanie konkretnego wsparcia finansowego i politycznego. Struktura niniejszego opracowania obejmuje ukazanie historyczno-politycznych uwarunkowań relacji unijno-rosyjskich, nie tylko dotyczących Bałkanów Zachodnich oraz wskazanie konkretnych przykładów rywalizacji obu tych podmiotów na wspomnianym obszarze. Artykuł wieńczy zakończenie, w którym pokrótce wskazano możliwe kierunki funkcjonowania państw Bałkanów Zachodnich oraz roli i miejsca w tym procesie tak Unii Europejskiej, jak i Federacji Rosyjskiej.

\section{Uwarunkowania relacji UE-Rosja}

Podstawą stosunków między Rosją a Unią Europejską jest Układ o Partnerstwie i Współpracy pomiędzy Unią Europejską a Federacją Rosyjską podpisany 24 czerwca 1994 r., który wszedł w życie 1 grudnia 1997 r. Analizując treść tego porozumienia nie sposób nie stwierdzić, iż ma ono bardzo ogólny charakter i odnosi się do takich elementów, jak współpraca polityczna, ekonomiczna czy gospodarcza. Niemniej już na tym przykładzie można dostrzec sposób uprawiania polityki przez Unię Europejską, wtedy jeszcze złożoną z 15 państw członkowskich. Ponad trzyletni okres oczekiwania od czasu podpisania do wejścia w życie tego dokumentu wynikał z faktu wyraźnego ochłodzenia relacji unijno-rosyjskich, spowodowanego pierwszą wojną w Czeczenii. Zdaniem polityków europejskich, Rosja próbując rozwiązać ów konflikt stoso- 
wała metody godzące w prawa człowieka i prawo międzynarodowe (Bodio, 2005, s. 31-32). „Blokowanie” wejścia w życie tego porozumienia było więc swego rodzaju narzędziem Unii Europejskiej, służącym wymuszeniu na Rosji zmianę ówcześnie prowadzonej polityki. Dostrzegając wady polityki zagranicznej i bezpieczeństwa Rosji, Unia Europejska postanowiła mimo wszystko kontynuować wzajemny dialog, starając się tym samym uspokoić nastroje wokół bilateralnych relacji. Dowodem na taką tezę było przyjęcie dokumentu pt. Wspólna strategia Unii Europejskiej wobec Rosji. Dokument ten został przedstawiony na szczycie Rady Unii Europejskiej 4 czerwca 1999 roku. Co istotne, w jego treści czytamy między innymi, że „Unia Europejska z zadowoleniem zauważa, że Rosja powróciła na właściwe miejsce w europejskiej rodzinie, w atmosferze przyjaźni, współpracy, sprawiedliwego uznania różnorodnych interesów i na podstawie wspólnych wartości, które tworzą dziedzictwo europejskiej cywilizacji" (Wspólna strategia, 1999). Dokument ten miał stanowić swoiste nowe otwarcie w relacjach unijno-rosyjskich i jednocześnie potwierdzać chęć włączenia Rosji w bieg ówczesnej polityki europejskiej. W dokumencie tym bowiem czytamy o planach UE wobec Rosji, które objęły tak istotne elementy, jak utrzymanie stabilności i bezpieczeństwa w Europie, wypracowanie na zasadzie bilateralnej współpracy nowych inicjatyw wobec regionów i państw trzecich w kwestiach dotyczących działań prewencyjnych i rozwiązywania konfliktów. Odniesiono się w nim także do kwestii stricte gospodarczych, jak potrzeba zbudowania spójnego dialogu gospodarczego, a także działania na rzecz powstania w Rosji gospodarki rynkowej, służącej nie tylko Rosjanom, ale także i Unii Europejskiej. Wydawało się więc, że początek XXI wieku będzie stanowił przełom w relacjach między Brukselą a Moskwą, czego skutkiem będzie intensyfikacja współpracy zarówno na płaszczyźnie politycznej, jak i gospodarczej. Tym bardziej, że podobny dokument, jak ten z czerwca 1999 roku przygotowała Rosja, przedstawiając go opinii publicznej 22 października 1999 roku. W jego treści możemy znaleźć podobne cele i sformułowania, odnoszące się do potrzeby rozwoju gospodarczego, czy aktywnej współpracy na rzecz europejskiego systemu bezpieczeństwa. Swego rodzaju novum omawianego dokumentu stanowi postulat zacieśniania współpracy między UE i Rosją w dziedzinie bezpieczeństwa, jednak bez polityki izolowania Sojuszu Północnoatlantyckiego i Stanów Zjednoczonych. Dla polityków europejskich te i podobne deklaracje były potwierdzeniem, że Rosja zaczyna (albo przynajmniej tak sugeruje), postrzegać Unię Europejską jako jeden organizm. Trzeba bowiem pamiętać, że przez całe lata 90. XX wieku, władze w Moskwie nie traktowały zbyt poważnie projektu europejskiego, rozwiązując swoje problemy i realizując interesy narodowe głównie poprzez bilateralne relacje z poszczególnymi państwami członkowskimi UE. W przypadku polityki rosyjskiej jest niezwykle trudno jednoznacznie stwierdzić, czy takie zachowanie było faktycznie realną oceną ówczesnej sytuacji międzynarodowej, czy raczej częścią zaplanowanej strategii mającej na celu jeszcze bardziej podzielić UE. Należy bowiem pamiętać, że z geopolitycznego punktu widzenia, wzmacniająca się Unia Europejska stanowiła bezpośrednie zagrożenie dla rosyjskich interesów w regionie, związanych chociażby z planowanym rozszerzeniem UE o kraje takie, jak Polska, Czechy czy w dalszej perspektywie Rumunia i Bułgaria. Trudno się spodziewać, aby rosyjscy stratedzy na początku XXI wieku całkowicie pominęli taką ewentualność. Mimo faktu drastycznego osłabienia ekonomiczno-politycznych możliwości oddzia- 
ływania Rosji na otoczenie międzynarodowe, władze w Moskwie w dalszym ciagu postrzegały swoją politykę zagraniczną w kategoriach mocarstwowości i potrzeby sprawowania „kontroli” nad przynajmniej częścią państw Europy, nie zapominając przy tym o dziedzictwie Związku Socjalistycznych Republik Radzieckich. Europa jednak jakby nie dostrzegała tego problemu i dosyć jasno prezentowała swój pozytywny stosunek do możliwości zacieśniania współpracy z Federacją Rosyjską. Dlatego też początek XXI wieku możemy nazwać tzw. polityką deklaratywnego partnerstwa między UE a Rosją. Nie wchodząc w szczegóły można stwierdzić, iż obie strony deklarowały chęć współpracy, nie potrafiły jednak w żaden sposób znaleźć choć jednego wspólnego mianownika, który nadałby relacjom unijno-rosyjskim konkretną i praktyczną wartość. Poza kolejno organizowanymi szczytami UE-Rosja nie wydarzyło się nic, co mogłoby faktycznie ugruntować i zacieśnić wzajemne relacje. Niemniej tym co mogło podtrzymywać nadzieję na rozwój poprawnych stosunków było szeroko rozumiane bezpieczeństwo. Potwierdzeniem tej tezy było m.in. przyjęcie deklaracji o rozbudowie dialogu i współpracy w sprawach polityki i bezpieczeństwa w październiku 2000 roku. To co jednak istotne z tego spotkania, to fakt poparcia przez Rosję istnienia Europejskiej Polityki Bezpieczeństwa i Obrony Unii Europejskiej. Rosja uznała, że nie jest ona zagrożeniem dla rosyjskich interesów i rosyjskiego bezpieczeństwa (Menkiszak, 2006). Dokonując pobieżnej analizy tego stanowiska można uznać je za przełomowe i dobrze rokujące dla wzajemnych relacji. Kiedy jednak przyjrzymy się temu, jak ówcześnie wyglądała europejska polityka obronna, to trudno się dziwić przyjęciu takiego stanowiska przez stronę rosyjską. W rzeczywistości bowiem polityka obronności UE była sumą potencjałów jej państw członkowskich, a te zaś nie przejawiały zbyt wielkiej chęci do przekazywania swoich zdolności militarnych UE. Zdecydowanie bardziej państwa te wolały wspierać Sojusz Północnoatlantycki jako faktyczny filar bezpieczeństwa militarnego Europy.

W kolejnych latach podpisywano liczne porozumienia, jak chociażby to z 2003 roku powołujące do życia Stałą Radę Partnerstwa czy też deklarację w dziedzinie bezpieczeństwa w 2003 roku w Rzymie. Zmianę wzajemnych relacji przyniósł 2004 rok, kiedy to w listopadzie wybuchła tzw. pomarańczowa rewolucja. W rozwiązanie sporu zaangażowała się Unia Europejska i jej politycy (m.in. prezydent Aleksander Kwaśniewski), co zostało negatywnie odebrane przez stronę rosyjska, uznającą ten fakt za ingerencję w wewnętrzne sprawy Ukrainy. Wydaje się, że od tego momentu stosunki UE z Rosją ulegały pogorszeniu. Z jednej bowiem strony Rosja uznawała Ukrainę za swoją strefę wpływów, zaś z drugiej w części państw członkowskich UE coraz śmielej mówiono o konieczności włączenia Kijowa w system euroatlantycki, rozumiany jako członkostwo zarówno w NATO, jak i Unii Europejskiej. Naprawie wzajemnych relacji nie pomagała sytuacja geopolityczna w Europie. Od 2004 roku państwami członkowskimi UE zostały Polska i kraje nadbałtyckie, z zasady krytyczne wobec rosyjskiej polityki. Kumulacją wzajemnych nieporozumień były lata 2005-2007, kiedy to w Polsce władzę przejęło Prawo i Sprawiedliwość. Rząd pod kierunkiem najpierw Kazimierza Marcinkiewicza, a później Jarosława Kaczyńskiego w bardzo konkretny sposób artykułował swoje cele polityki zagranicznej wobec Rosji, wykorzystując do ich realizacji forum Unii Europejskiej. To polskie stanowisko doprowadziło do zablokowania podpisania umowy o partnerstwie strategicznym między Unią Europejską a Rosją. Ten 
przykład dowodzi, że w łonie samej Unii Europejskiej pojawiły się państwa niechętne angażowaniu Rosji w politykę bezpieczeństwa, co wyraźnie utrudniało unormowanie stosunków politycznych. Z drugiej jednak strony, Rosja kontynuowała instrumentalne wykorzystywanie części państw członkowskich UE do realizacji strategicznych dla siebie interesów, podając za przykład niemiecko-rosyjską inwestycję Gazociaggu Północnego. Oba te przykłady pokazują, że wśród państw członkowskich UE nie było konsensusu co do miejsca i roli Federacji Rosyjskiej w unijnej polityce zagranicznej. Dla jednych była ona strategicznym partnerem (zwłaszcza w kwestiach gospodarczych), a dla drugich największym zagrożeniem i cieniem z przeszłości (Polska, kraje nadbałtyckie). Próba dzielenia przez Rosję państw członkowskich na „lepsze” i „gorsze" tak naprawdę nie jest niczym nowym i z jednej strony od lat służy wprowadzaniu destabilizacji w szeregach samej UE poprzez podważanie europejskiej solidarności, a z drugiej strony skutecznie służy realizacji celów narodowych, za przykład podając dobre relacje z Niemcami, Włochami czy Węgrami pod rządami Wiktora Orbana.

Nie bez znaczenia pozostaje także polityka samej Rosji i wynikające z niej implikacje dla relacji z Unią Europejską. Powszechnie wiadomym jest, że Rosja nigdy nie wyrzekła się polityki mocarstwowości i przez cały czas po 1990 roku dążyła do jej skutecznej realizacji. Część badaczy twierdzi, że czas przejściowy, obejmujący lata z początku XXI wieku, nie pozwolił jednoznacznie stwierdzić, że wskutek problemów wewnętrznych Rosja została wykluczona z grona światowych decydentów (Przybyła, 2011, s. 130). Skrajnym tego przykładem, uderzającym także w interesy unijne, były wydarzenia z Gruzji w 2008 roku. Pamiętajmy, że na początku 2005 roku w specjalnym referendum mieszkańcy Gruzji opowiedzieli się za członkostwem swojego kraju w NATO. Wojna w Abchazji i Osetii Południowej była z jednej strony próbą sił dla Rosji i UE, a z drugiej ukazała determinację Federacji Rosyjskiej w realizacji celów polityki zagranicznej (później powielonych na Krymie). Trudno bowiem uznać za sukces działania ówczesnych polityków europejskich, w tym Nicolasa Sarkoziego, prezydenta Francji, która sprawowała w tym czasie Prezydencję w Radzie Unii Europejskiej. Poza wstrzymaniem działań wojskowych prowadzonych przez stronę rosyjską nie udało się utrzymać integralności terytorialnej Gruzji. Innymi słowy, to Rosja zrealizowała swój cel, zaś Unia Europejska tak naprawdę mogła się temu tylko przyglądać i ostatecznie zaakceptować stan rzeczy. Wydaje się, że wojna w Gruzji była pełnym potwierdzeniem tezy, że Rosji wcale nie zależało na faktycznym budowaniu pozytywnych relacji z Unią Europejska, tylko uprawianiu swoistej „gry pozorów”, przynoszącej określone korzyści gospodarcze. Przykre i jednocześnie zastanawiające jest to, że europejscy politycy nie byli w stanie w odpowiedni sposób zareagować na „ową" grę Rosji. Nie byli także w stanie skutecznie zareagować na wydarzenia na Ukrainie, rozpoczęte w kwietniu 2014 roku. Ponownie, to nie UE jako całość negocjowała tzw. porozumienia mińskie, tylko przedstawiciele Niemiec i Francji (Wilk, Olszański, Górecki, 2016). Dowodzi to braku posiadania przez Unię Europejską konkretnej strategii wobec Rosji i jej polityki zagranicznej. Warto w tym miejscu jednak postawić pytanie, czy Unia Europejska w ogóle powinna mieć taką strategię? Jest to przecież organizacja międzynarodowa, będąca co do zasady wtórnym uczestnikiem stosunków międzynarodowych. W tym kontekście zrozumiałe jest, że prezydent Putin preferuje dialog z kanclerz Angelą Merkel niż z Przewodniczącym Rady Europejskiej 
Donaldem Tuskiem? Niezwykle trudno jest udzielić jednoznacznej odpowiedzi na tak formułowane pytania. Nie zmienia to jednak faktu, że współczesne stosunki unijnorosyjskie to katalog dobrych chęci i nic poza tym. Pewnym unormowaniem relacji byłaby decyzja o zniesieniu czy chociaż zawieszeniu sankcji gospodarczych nałożonych przez UE na Rosję, o czym nota bene coraz głośniej mówi część państw członkowskich UE. Nie da się bowiem ukryć, że UE, jej państwa członkowskie i Rosja są od siebie zależne, nawet mimo nałożonych sankcji gospodarczych na Rosję. Być może jest to dobry fundament dla pogłębiania obustronnych stosunków. Nie da się jednak przewidzieć jak potoczą się dalsze losy omawianej współpracy, a dużo w tej materii zależy od polityki Rosji. Niezwykle ważne jest jaki kierunek wybierze ona w swojej polityce zagranicznej i czy w dalszym ciagu będzie próbowała „zagospodarować” nie tylko Ukrainę i Białoruś, ale także państwa Bałkanów Zachodnich, które od wielu lat starają się o uzyskanie członkostwa w Unii Europejskiej.

\section{UE-Rosja na obszarze Bałkanów Zachodnich}

Bałkany Zachodnie, rozumiane jako państwa byłej Socjalistycznej Federacyjnej Republiki Jugosławii obecnie wydawałoby się, że daleko za sobą pozostawiły wojnę z lat dziewięćdziesiątych i nieustająco narastające konflikty. Niestety historia w państwach bałkańskich nie pozostaje historia, lecz często zamienia się w teraźniejszość, prowokując coraz to nowe zarzewia sporów i konfliktów o różnorodnym wymiarze i sile, tym bardziej gdy pojawiają się dodatkowe implikacje w postaci problemów gospodarczych, prawnych i rozwojowych. Napięcia zwiększają się w tym regionie w miarę wzrastania zaangażowania aktorów trzecich takich na przykład jak: Unia Europejska, Federacja Rosyjska, czy też Turcja (Muś, 2015). Specyfika regionu, kluczowego z punktu widzenia położenia i potencjału, powoduje, że od wieków jest on polem, w dużej mierze, rywalizacji aktorów wewnętrznych i zewnętrznych, z czego ci drudzy stanowią ewidentny czynnik zapalny, lub też prowokują, często celowo, przyrost zagrożeń w celu osiagnięcia założonych efektów (Babić, Jakimowicz-Ostrowska, 2014). Unia Europejska w tym zakresie odgrywa zgoła inną rolę, którą możemy raczej określić jako pozytywne oddziaływanie poprzez konstruktywną i stabilizacyjną obecność. Niemniej jednak owa obecność traktowana jest przez Federację Rosyjską jako element ingerujący w jej interesy, tudzież samoistnie przypisywaną strefę wpływów (Stępniewski, 2015). Tym samym owa aktywność obu graczy prowokuje zarówno rywalizację pomiędzy nimi, jak i zaostrza rywalizację i odradza konflikty pomiędzy państwami regionu, które realizują dualną politykę zagraniczną w celu uzyskania korzystnych warunków.

Geneza relacji Federacji Rosyjskiej i Unii Europejskiej z państwami bałkańskimi jest zróżnicowana w zależności od podmiotu nie tylko ze względu na różnice $\mathrm{w}$ ich podejściu strategicznym, wizji regionu czy podstaw ideologicznych, lecz przede wszystkim w odniesieniu do okresu trwania wzajemnych stosunków i ich historycznych uwarunkowań. Federacja Rosyjska, jeszcze jako Związek Radziecki i Carska Rosja była obecna na terytorium Półwyspu Bałkańskiego przez kilka ostatnich wieków, ogrywając różnorodne role i wywierając znaczący wpływ na jego kształt poli- 
tyczny, społeczny i kulturowy. Unia Europejska natomiast szczególnie mocno zaangażowała się w tym regionie dopiero w latach dziewięćdziesiątych, a więc po rozpadzie Jugosławii i zaistnieniu konieczności realnego zaangażowania się w rozwiązywanie bieżących problemów tam występujących. Pierwsze znaczące działania, po klęsce jej starań związanych z wygaszaniem konfliktu na Bałkanach, Unia Europejska podjęła w 1999 roku ustanawiając Proces Stabilizacji i Stowarzyszenia, jako element finansowego, politycznego, gospodarczego i kooperacyjnego oddziaływania (Olszewski, 2010). Proces ten był pierwszym instrumentem powszechnie stosowanym w celu stabilizacji państw regionu, jak i wzmacniania oddziaływania Unii Europejskiej, tworzenia stabilnych podstaw prodemokratycznych i kształtowania pokojowego współistnienia. Proces ten przeradzał się sukcesywnie w Umowy o Stabilizacji i Stowarzyszeniu, którymi od 2016 roku objęte są wszystkie państwa bałkańskie. W tym zakresie z jednej strony można uznać, że stanowią one instrument wspomagający proces budowania demokratycznych państw w regionie, mechanizm rozwijający zachowania prospołeczne i porządkujące system społeczny i polityczny oraz element wywierania realnego wpływu na przemiany zachodzące w państwach nim objętych. Najszybsze zmiany zachodzą oczywiście w wymiarze kompetencji wyłącznych Unii Europejskiej. Kolejną kwestią wykorzystywaną do realizacji polityki Unii Europejskiej na terenie Bałkanów Zachodnich jest koncepcja budowy współpracy regionalnej w oparciu o wyselekcjonowane zadania z zakresu na przykład zarządzania granicami, czy też zwalczania zorganizowanej przestępczości. Współpraca ta jest organizowana między innymi przez Radę Współpracy Regionalnej i przy pomocy Południowo-Wschodniego Procesu Współpracy (SEECP). Ponadto użytecznym instrumentem jest także Środkowo-Europejska Umowa o Wolnym Handlu (CEFTA). Projekty te jednak w dużej mierze uległy swoistej degradacji w zakresie siły swojego oddziaływania po słowach Jean Clauda’a Junckera, który zapowiedział, że państwa bałkańskie nie moga oczekiwać członkostwa i mogą czekać na nie bardzo długo. Ich osłabienie wynika z narastającego rozczarowania elit politycznych tych państw, które nie chcą realizować kolejnych reform, wdrażania rozwiązań prawnych i założeń wynikających z wytycznych Komisji Europejskiej zawartych na przykład w Planach Działania. Niemniej jednak skomplikowana sytuacja polityczna w Macedonii, nierozwiązane problemy w Bośni i Hercegowinie oraz skomplikowane i silnie obciążone wzajemną niechęcią relacje pomiędzy Serbią i Kosowem nie tylko motywują stanowisko Komisji Europejskiej, lecz także tworzą podłoże dla rywalizacji rosyjsko-unijnej i zdecydowanie utrudniają zadanie państwom unijnym (Paruch, 2017; Śmigielski, 2007; Olszewski, 2009). Tym samym wzrasta nie tylko aktywność Federacji Rosyjskiej w regionie, lecz także skłonność poszczególnych polityków w tych państwach do nawiązywania bliższych relacji, co w szczególności wynika z chęci realizacji interesów gospodarczych. Ponadto zdecydowanie komplikuje się sytuacja Czarnogóry, która jest państwem o dużym odsetku inwestycji rosyjskich oraz mierzy się z bardzo intensywnymi działaniami kreującymi dominującą rolę Federacji Rosyjskiej. Tym samym nie tylko przecinają się na Bałkanach, dwie odmienne wizje ładu międzynarodowego, światopoglądowo zdecydowanie bardzo od siebie odległe, lecz również obciążone rywalizacją cywilizacyjną i ogólnymi sympatiami. Przykładem może być silna więź serbsko-rosyjska, która kształtowała się przez wieki dodatkowo została wzmocniona wojną z lat dziewięćdziesiątych oraz powszech- 
nym uznaniem niepodległości Kosowa (Tanner, 2017). Serbowie wprost oczekują od Federacji Rosyjskiej pomocy w zakresie unieważnienia niepodległości Kosowa i odzyskania go na rzecz swojego państwa. Takie oczekiwania i prowadzone w związku z nimi działania z jednej strony, wpisują się w dążenie do utrzymania swojego znaczenia w regionie, z drugiej, stanowią przeciwwagę dla coraz aktywniej i silniej naciskającej Unii Europejskiej, wręcz żądającej wdrażania rozwiązań z jej punktu właściwych, jednak w całości nieuwzględniających realiów regionu. Z tej sytuacji wynika kilka zagrożeń, od narastania sporu, poprzez silną destabilizację, aż do wybuchu otwartego konfliktu - tudzież wojny. Problem ten bez watpienia znajduje swoje odzwierciedlenie również w przypadku Bośni i Hercegowiny, która nadal znajduje się pod wpływem rozwiązań z Dayton i nieudolnych działań Unii Europejskiej. Ponowny wybuch wojny w tym państwie jest nawet o wiele bardziej prawdopodobny niż w przypadku Serbii i Kosowa. Niemniej jednak, jak uważa John R. Schindler rodząca się destabilizacja jest niewątpliwie wynikiem oddziaływania Federacji Rosyjskiej i jej niewattpliwie skrupulatnie prowadzonych działań w zakresie Serbów, zarówno w Serbii jak i Republice Serbskiej w Bośni i Hercegowienie (Schinldler, 2017). Zdecydowanie obawy powinny wzbudzić wspólne manewry Serbii, Rosji i Białorusi oraz dostawy broni, samolotów Mig-29 i czołgów do Serbii. W grudniu 2016 roku w Belgradzie odbył wizytę Serei Lavrov, który rozmawiał na temat rozwoju współpracy rosyjsko-serbskiej, szczególnie w zakresie gospodarczym, wojskowym i politycznym. Z jednej bowiem strony Rosja potrzebuje Serbii, aby móc budować swoje wpływy w regionie, a Serbia potrzebuje Rosji, aby móc kontynuować swoje starania w kwestii Kosowa (Biserko, 2016). Niemniej jednak, szczególnie Serbowie zdają sobie sprawę z konieczności współpracy z Unią Europejską i nieuchronności utrzymania kursu integracyjnego, przede wszystkim w celu realizacji dalszej odbudowy państwa i wzmacniania jego potencjału gospodarczego, co znalazło swój wyraz w zgodzie na europejską mediację między Serbią i Kosowem w 2011 roku. Ten kurs jednakże jest obciążony wcześniej już wspominanymi żądaniami Unii Europejskiej w kwestii regulacji stosunków serbsko-kosowskich, a to nie znajduje poparcia, a wręcz budzi silny sprzeciw w serbskim społeczeństwie, gotowym za cenę osłabienia stosunków z Unią Europejską na odrzucenie polityków pro-unijnych. Niemniej jednak owa rywalizacja rosyjsko-unijna poza sferą polityczną skupia się także na działaniach gospodarczych, a więc w szczególności na rozwoju stosunków handlowych. Jak jednak pokazuje dokument zatytułowany European Union, Trade in goods with Western Balkans 6, opublikowany przez Dyrekcję Generalną ds. Handlu, Komisji Europejskiej to Unia Europejska zarówno w zakresie importu jak i eksportu z państwami bałkańskimi dominuje nad Federacją Rosyjską. Według opublikowanego dokumentu handel z Unią to $67,9 \%$ całkowitego importu i $84,7 \%$ całkowitego eksportu. Podczas gdy handel z Rosją to 5,2\% całkowitego importu i 3,9\% całkowitego eksportu (w całkowitych obrotach handlowych) Unia reprezentuje $74,1 \%$, podczas gdy Rosja tylko 4,7\%, z udziałem mniejszym niż Chińska Republika Ludowa 5,5\%. Powyższe dane jasno wskazują, że Unia jest w tym zakresie dominującym partnerem dla państw bałkańskich, i nawet jeśli często w związku ze swoimi wymaganiami, oczekiwaniami i żądaniami kierowanymi w stronę tych państw jest co najmniej kłopotliwym partnerem, to nie może być lekceważona i strategicznie stanowi jedyny możliwy kierunek rozwoju ich relacji międzynarodowych. Proble- 
mem, z którym Unia musi jednak sobie radzić, jest dominująca rola Rosji jako dostawcy energetycznego, lub też jako partnera biznesowego państw bałkańskich. Niemniej jednak Władimir Putin, ogłaszając brak realizacji poszczególnych projektów energetycznych, pomógł Unii Europejskiej i umożliwił jej prezentację alternatywnych rozwiązań, które co prawda, jeszcze się nie pojawiły na agendzie, jednakże chociażby poprzez rozwijanie współpracy gospodarczej i środki pomocowe przeznaczane także na wzmocnienie sektora energetycznego zaistniały realnie. Unia Europejska zainwestowała także w zakresie rozwoju pomocy przedakcesyjnej, którą objęła państwa Bałkanów Zachodnich. Skierowała środki do Bośni i Hercegowiny, Macedonii, Czarnogóry, Serbii, Kosowa, a także Albanii i Turcji. W głównej mierze objęły one takie zadania jak reforma administracji publicznej, zasady prawa, stabilną gospodarkę, politykę społeczną, rolnictwo i rozwój terenów wiejskich. Nowy zakres Instrumentu Partnerstwa obejmuje lata 2014-2020 i zbudowany jest w oparciu o strategiczne opracowania dotyczące poszczególnych państw. Objęto nim tak zwane predefiniowane sektory, do których zaliczono: demokrację, dobre zarządzanie, wzrost i konkurencyjność. Dla poszczególnych państw na lata 2014-2020 zaplanowano następujące kwoty: Bośnia i Hercegowina - 165,8 milionów euro; Macedonia - 664,2 milionów euro, Serbia - 1508 miliona euro; Kosowo - 645,5 miliona euro (ENI - 2014-2020).

Kolejnym elementem spornym pomiędzy Federacją Rosyjską a Unią Europejską jest kwestia gwarancji bezpieczeństwa na Półwyspie Bałkańskim, zdecydowanie wzmacniana poprzez współpracę państw regionu zarówno z Unią Europejska, jak i Organizacją Paktu Północnoatlantyckiego. Nie bez znaczenia jest członkostwo Albanii i Czarnogóry w NATO, które w jasny sposób definiuje kierunek ich działania politycznego i podejście geopolityczne. Federacja Rosyjska w tym zakresie stała się szczególnie aktywna w trzech wymiarach geograficznych, podejmując próby oddziaływania na Czarnogórę, jeszcze przed jej wstąpieniem do struktur NATO oraz na Bośnię i Hercegowinę i Serbię obecnie. Dostawy broni, nawet jeśli z pozoru małe i nie znaczące $z$ perspektywy strategicznej, w całej rozciągłości definiują rosyjskie podejście i wskazują na żywotne zainteresowanie Rosji tym regionem. De facto dochodzi do zderzenia odmiennych ideologii i wizji rzeczywistości, w których panslawizm staje w opozycji do zachodnich koncepcji ładu społecznego i kulturowego. Silny wpływ ideologiczny, wykorzystujący miejsce państwa na mapie politycznej Europy, możemy zaobserwować nie tylko w Serbii, lecz także w Bułgarii. Polityka Federacji Rosyjskiej z tak zwanego łagodnego zaangażowania i szerokiego wspierania Serbii, za czasów Jelcyna, zmieniła się diametralnie w dobie rządów Władimira Putina, który uznał region bałkański za znaczący dla polityki rosyjskiej i kluczowy z punktu widzenia oddziaływania z jego perspektywy na całą Europę i Unię Europejską. Głównymi punktami rosyjskiej polityki w tym zakresie ustanowiono udzielanie pożyczek, projekty energetyczne, rozwijanie wymiany handlowej oraz podejmowania szeregu innych inwestycji, między innymi także w turystyce. Przykładem na takie działania jest monopolistyczna pozycja rosyjskich firm energetycznych w Serbii, Bułgarii i Republice Serbskiej. Rywalizacja pomiędzy Federacją Rosyjską a Unią Europejską, przekłada się również na rywalizację i narastanie napięć wewnątrz regionu, wyrażane albo poprzez bezpośrednie konflikty pomiędzy państwami lub pośrednio poprzez na przykład 
poparcie dla sankcji przeciwko Rosji udzielone przez Czarnogórę, ale nie udzielone przez Serbię, Bośnię i Hercegowinę, czy też Macedonię.

\section{Zakończenie}

Bez wątpienia rywalizacja unijno-rosyjska na obszarze Bałkanów Zachodnich ma miejsce. Trudno jest jednak wskazać tylko jedno kluczowe jej uwarunkowanie. Każda z trzech stron (UE, Rosja, państwa Bałkanów Zachodnich) borykają się z określonymi problemami natury nie tylko politycznej czy gospodarczej, ale przede wszystkim strategicznej. Unia Europejska musi sobie wreszcie odpowiedzieć na pytanie o zdolność absorpcji nowych państw członkowskich. Tę samą decyzję muszą podjąć jej państwa członkowskie. Z kolei Federacja Rosyjska, skoncentrowana obecnie na Ukrainie, musi zaoferować społeczeństwom państw Bałkanów Zachodnich coś na tyle atrakcyjnego, że te zdecydują się porzucić marzenia o integracji europejskiej i potencjalnym członkostwie w UE. W najgorszej sytuacji są jednak państwa Bałkanów Zachodnich. Można stwierdzić, że biorą one udział w swoistej grze o swoją przyszłość, mając na nią stosunkowo niewielki wpływ. Nie pomagają im rzecz jasna wewnętrzne spory i starcia na tle narodowościowym i historycznym. Nie są także w stanie występować jako jeden zorganizowany (choć niesformalizowany), wspierający się wzajemnie blok państw, jak to miało miejsce np. w przypadku Grupy Wyszehradzkiej (przy uwzględnieniu całej odmienności regionów). Najbliższe kilka lat zdecyduje, jaką drogę wybiorą państwa Bałkanów Zachodnich, a przynajmniej część z nich. Można mieć tylko nadzieję, że będzie to w pełni suwerenna decyzja społeczeństw tych państw i polityków kierujących się wyłącznie dobrem swoich obywateli.

\section{Bibliografia}

Adamishin A. (2015), The Yugoslav Prelude. A Prototype for Modern Approaches to „Peacemaking”, ,Rocznik Instytutu Europy Środkowo-Wschodniej”, R. 13, z. 5.

Babic M., Jakimowicz-Ostrowska I. (red.) (2014), Bałkany w XXI wieku Problemy konsolidacji i integracji, Wydział Dziennikarstwa i Nauk Politycznych UW, Warszawa.

Bechev D. (2017), The West needs to call Russia's bluff in the Balkans, „LSE European Politics and Policy (EUROPP) Blog".

Bieleń S., Raś M. (red.) (2008), Polityka zagraniczna Rosji, Difin, Warszawa.

Biserko S. (2016), The warp of the Serbian identity. Anti-westernism, Russophilia, Traditionalism..., Helsiniki Comittee for Human Rights in Serbia, Belgrad.

Błaszczuk M. (2006), Perspektywa członkostwa Bałkanów Zachodnich w Unii Europejskiej, „Wspólnoty Europejskie", nr 12.

Bodio M. (2005), Stosunki między Uniq Europejska a Federacja Rosyjskq. Stan i perspektywy rozwoju, Dom Wydawniczy Elipsa, Warszawa.

European Neighbourhood-wide measures, EU Commission Directorate General for Development and Cooperation - EUROPAID. 
Grammatikas V. (2015), A Different Perspective? Russian Interpretation of the International Law in the Post-Cold War Era, ,Rocznik Instytutu Europy Środkowo-Wschodniej”, R. 13, z. 5.

Hoxha A., Ahmeti A., Musliu A. (2015), Russian In uence in the Western Balkans. Carrot or Stick?, „Rocznik Instytutu Europy Środkowo-Wschodniej”, R. 13, z. 5.

Kaszuba M., Stempień M. (2017), Surowce energetyczne w polityce Federacji Rosyjskiej, Pracownia Wydawnicza Wydziału Humanistycznego Uniwersytetu Przyrodniczo-Humanistycznego w Siedlcach, Siedlce.

Łoskot A. (2005), Bezpieczeństwo dostaw rosyjskiego gazu do UE: kwestia połqczeń infrastrukturalnych, Ośrodek Studiów Wschodnich im. Marka Karpia, Warszawa.

Menkiszak M. (2006), Rosja wobec Unii Europejskiej: kryzys ,,strategicznego partnerstwa”, „Prace OSW", $\mathrm{nr} 22$.

Muś J. (2015), Peripheral Position of the Balkans and its Future Relations with Russia, „Rocznik Instytutu Europy Środkowo-Wschodniej”, R. 13, z. 5.

Obad O. (2015), Mental Maps on the Negotiating Table. Symbolic Geographies in Croatian Accession to the European Union, „Rocznik Instytutu Europy Środkowo-Wschodniej”, R. 13, z. 5.

Olszewski P. (2010), Bałkany Zachodnie w polityce Unii Europejskiej, „Myśl Ekonomiczna i Polityczna", nr 1.

Olszewski P., Kapuśniak (Stępniewski) T., Lizak W. (red.) (2009), Bezpieczeństwo międzynarodowe: wyzwania i zagrożenia XXI wieku, Wyższa Szkoła Handlowa, Radom.

Papapostolou A. et al. (2017), Exploring opportunities and risks for RES-E deployment under Cooperation Mechanisms between EU and Western Balkans: A multi-criteria assessment, „Renewable and Sustainable Energy Reviews", nr 80.

Paruch W. (2017), Między polityzacja etnosu a etnicyzacja demosu: refleksje o polityce narodowej na Batkanach, „Annales Universitatis Mariae Curie-Sklodowska, sectio M - Balcaniensis et Carpathiensis", nr 1.1-2.

Programming of the European Neighbourhood Instrument (ENI) - 2014-2020.

Przybyła K. (2011), Wspótpraca, rywalizacja czy konflikt? Stosunki Unii Europejskiej i Federacji Rosyjskiej, „Myśl Ekonomiczna i Polityczna”, nr 1-2.

Samokhvalov V. (2017), Russian-European Relations in the Balkans and Black Sea Region: Great Power Identity and the Idea of Europe, Palgrave Macmillan, Cham.

Schindler J. R. (2017), President Trump's First Foreign Policy Crisis: Balkan War Drums Beat Again, Observer, http://observer.com/2017/01/nato-deploying-troops-poland-baltics-vladimirputin/, 25.01.2017.

Stanchev S. (2015), Russia's State-Owned Companies and Contemporary Bulgarian Political and Economic Landscape, „Rocznik Instytutu Europy Środkowo-Wschodniej”, R. 13, z. 5.

Stępniewski T. (2015), Russia in Global Politics in the Context of the Western Balkans, „Rocznik Instytutu Europy Środkowo-Wschodniej”, R. 13, z. 5.

Strategic Priorities 2014-2020 and Multi-annual Indicative Programme 2014-2017.

Śmigielski R. (2007), Kwestia kosowska w polityce Federacji Rosyjskiej, „Polski Przegląd Dyplomatyczny", nr 5.

Tanner M. (2017), Serbia, Kosovo Should Swap Land, Ivor Roberts Says, http://www.balkaninsight. com/en/article/serbia-kosovo-should-swap-land-ivor-roberts-says-02-08-2017).

Wilk A., Olszański T. A., Górecki W. (2016), Porozumienie mińskie - rok gry pozorów, „Analizy OSW", https://www.osw.waw.pl/pl/publikacje/analizy/2016-02-10/porozumienie-minskierok-gry-pozorow, 10.02.2016.

Woźniak P. (2015), Zniecierpliwione Bałkany Zachodnie, „Rzeczpospolita” z 1.06.2015 r. 
Wspólna strategia Unii Europejskiej wobec Rosji z 4 czerwca 1999 roku, II załącznik z posiedzenia Rady Europejskiej w Kolonii (3-4 czerwca 1999 r.).

\section{Streszczenie}

W niniejszym artykule autorzy prezentują relacje pomiędzy Federacją Rosyjską a Unią Europejską w kontekście rywalizacji o wpływy na obszarze Bałkanów Zachodnich. Szczególną uwagę autorzy zwracają na przecinające się linie interesów i niemniej ważne aspekty historycznej partycypacji w stosunkach wewnątrz regionu obu aktorów. W artykule zarówno poruszono kwestie polityczne, społeczne jak i gospodarcze, które stanowią meritum wzajemnych relacji zarówno na przestrzeni Federacja Rosyjska - Unia Europejska, jak i pomiędzy oboma aktorami a państwami regionu.

Słowa kluczowe: Unia Europejska, Federacja Rosyjska, Bałkany Zachodnie, rywalizacja, demokracja, panslawizm

\section{The rivalry between the European Union and Russia in the Western Balkans}

\section{Summary}

In this article, the author's present relations between the Russian Federation and the European Union in the context of competition for influence in the Western Balkans. Particular attention is paid to the intersecting lines of interest and, nevertheless, important aspects of historical participation in intra-regional relations between the two actors. The article addresses both political, social and economic issues, which are the merits of mutual relations both within the Russian Federation - the European Union as well as between the two actors and the countries of the region.

Key words: European Union, Russian Federation, Western Balkans, rivalry, democracy, Panslavism 